\title{
Reproductive biology of Hechtia schottii, a dioecious Bromeliaceae, in Mexico
}

\author{
Ivón M. Ramírez Morillo, Francisco Chi May, Germán Carnevali Fernández-Concha \\ \& Filogonio May Pat \\ Centro de Investigación Científica de Yucatán, A.C., Herbario CICY, Calle 43 \# 130, Colonia Chuburná de Hidalgo, \\ Mérida 97200, Yucatán, México. Phone: (999) 9428330 ext. 232. Fax: (999) 9813900; ramirez@cicy.mx
}

Received 22-XI-2005. Corrected 31-I-2007. Accepted 03-X-2007.

\begin{abstract}
Hechtia schottii is a terrestrial, rosetofilous, dioecious, polycarpic succulent herb, that grows mainly in shrubby associations, and less frequently, in secondary low caducifolious forests, both on calcareous soils or limestone outcrops in Yucatan and Campeche States, Mexico. We studied phenology, floral and pollination biology, and breeding system at Calcehtok, Yucatan, during two flowering seasons. Plants bloom mainly during the dry season (November-April) and disperse seeds during the rainy season (May-October). Both floral morphs have diurnal anthesis; pollen is removed ca. $1 \mathrm{~h}$ after anthesis starts and both floral morphs are visited by several insect species, especially bees, but results suggest that the introduced honey bee, Apis mellifera, is the pollinator. Controlled crossings show that the species is functionally dioecious and requires to be serviced by pollinators based on fruit setting only in unassisted cross pollination crosses. Rev. Biol. Trop. 56 (1): 279-289. Epub 2008 March 31.
\end{abstract}

Key words: Hechtia schottii, Bromeliaceae, reproductive biology, dioecy, pollinators, Mexico, Yucatán.

Hechtia Klotzsch is a genus of more than 55 species; except for five of them, the group is restricted to Mexico (Burt-Utley and Utley 1993). It is characterized by its dioecious members (except by $H$. gayorum L.W. Lenz, a monoecious species; Lenz 1995), with restricted geographical ranges (i.e. each species known from one or a few populations) and associated with rocky soils, of calcareous or volcanic origin.

Plants of the genus are terrestrial or lithophytic, rosetofilous; the leaves armed with spines or less often, finely serrulate, as short as $20 \mathrm{~cm}$ but usually longer and up to $1.5 \mathrm{~m}$ long; the inflorescences are lateral or terminal, racemose or more commonly paniculate, from 50 $\mathrm{cm}$ high and in some cases up to 2.5-3 m long, with numerous, minute $(6-7.5 \mathrm{~mm}$ long) flowers; these mostly with white petals, more rarely petals bluish, lilac, green, red or yellowish.
Details of floral biology, breeding systems and pollination biology are fundamentally unknown for members of Hechtia.

The most commonly accepted (Smith and Downs 1974, 1977, 1979) classification scheme (albeit artificial) recognizes three subfamilies in the Bromeliaceae, differing in leaf, flower, seed and fruit morphology. Dioecy in Bromeliaceae has been reported for all three: Tillandsioideae (some populations of taxa in the genus Catopsis Griseb.), Bromelioideae (Aechmea maria-reginae $\mathrm{H}$. Wendland and the monospecific genus Androlepis Houllet), and in Pitcairnioideae: Hechtia; some Dyckia Schult. f. spp. and Cottendorfia Schult. f. spp. present unisexual flowers, indicating a potentially different breeding systems in a family overwhelmingly dominated by taxa with hermaphrodite flowers (Benzing et al. 2000). Predominantly dioecious clades concentrate 
in northern Central America and Mexico, with a few a species ranging southward into Costa Rica (Aechmea maria-reginae and Androlepis skinneri (K. Koch) Houllet) (Benzing et al. 2000). On the other hand, Catopsis species (for example, C. nutans (SW.) Griseb.) characterized by hermaphrodite populations in South America and Florida, typically feature completely dioecious populations in Central America (Palací 1997).

Dioecy has arisen independently in the flowering plants many times (Bawa 1980, Renner and Ricklefs 1995, Weiblen et al. 2000) via monoecy (Renner and Ricklefs 1995) or possibly involving transient intermediates such as gynodioecy (Weiblen et al. 2000). About six percent of all flowering plant species are dioecious (Renner and Ricklefs 1995). Despite multiple publications attempting to explain the possible origin of dioecy and its correlates in different plant groups, no hypotheses have been put forward to explain the evolution of dioecy in the Bromeliaceae. Benzing et al. (2000) suggests that insight into the evolution of dioecism in Catopsis should emerge as knowledge on bromeliad phylogeny increases.

Explanations advanced to account for the fact that dioecious species have been more that most of the dioecious bromeliads occur in Mesoamerica and southern Mexico include the contention that dioecious species have been more successful conquering the geographical area and have diversified and radiated there since then (D. Benzing 2000, pers. comm.); the possibility that selective pressures (probably breeding systems or pollinators) have favored the evolution of dioecy in the region; or sex resource allocation differences probably related with xeric conditions. None of these hypotheses have been tested.

The presence of dioecy in the family has been supported on morphological evidence, i.e.: two floral morphs residing on different individuals and an apparent lack of functionality of the pistillode and the staminodes), but functional dioecy has not been tested in the field. Opposite situations are also documented in different plant groups with cryptic dioecy, when one of the sexual functions is suppressed, functioning as unisexual (Humeau et al. 1999, among others). Furthermore, the report of a monoecious species in the genus Hechtia ( $H$. gayorum) points out to the possibility of more than a single breeding system in the group, stressing the fact that detailed morphological and reproductive biology studies should be carried out. Thus, it becomes necessary to perform controlled crosses in natural populations to investigate the breeding systems of particular taxa. In Bromeliaceae, such experiments (as well as any kind of pollination studies), are scarce and have never been carried out in the dioecious species of the family.

This contribution addresses questions related to the phenology, floral biology, breeding systems, and pollination biology of Hechtia schottii Baker in Calcehtok, Yucatán, Mexico with the aim to contribute to fill in the void on the knowledge of these aspects in the Bromeliaceae. We also aim at providing additional evidence which will eventually be useful to address-the question of the origin of the geographical restriction of bromeliad dioecy to Mexico and Central America.

\section{MATERIALS AND METHODS}

Study site: for the purposes of this study, the Yucatan Peninsula is here circumscribed politically as encompassing the Mexican states of Campeche, Quintana Roo, and Yucatan. This area consists of a rocky, Terciary basement, flat and without rivers. The climate is basically tropical, with average temperature of $24-26{ }^{\circ} \mathrm{C}$. There are three marked stations (Duch 1988), rainy from May to November, "nortes" from December to February, and dry from March to May. Precipitation goes from 500-600 mm in the north to almost $1800 \mathrm{~mm}$ in the south (Ferrusquía-Villafranca 1993).

The study site is located at the southwestern portion of the Yucatan state $\left(20^{\circ} 34^{\prime} 00^{\prime \prime}\right.$ $\left.\mathrm{N}, 89^{\circ} 54^{\prime} 46^{\prime \prime} \mathrm{W}\right)$, ca. $15 \mathrm{~m}$ above sea level, near the village of Calcehtok and the caverns of the same name. Vegetation is dominated by 
variously disturbed secondary low caducifolious forest (henceforth SLCF) (Olmsted et al. 1999) with tree species such as Bursera simaruba (L.) Sarg. (Burseraceae), Gymnopodim floribundum Rolfe (Polygonaceae), Acacia gaumeri S.F. Blake and Caesalpinia gaumeri Greenm. (Fabaceae); in a mosaic with several kinds of herbaceous and rosetofilous vegetation associations on rocky soils. Here, species such as $H$. schottii, Agave angustifolia Haw. (Agavaceae), Viguiera dentata (Cav.) Spreng. (Asteraceae), Ipomoea heredifolia L., I. crinicalyx S. Moore, Jacquemontia nodiflora (Desr.) G. Don, J. pentantha (Jacq.) G. Don (Convolvulaceae), Cnidoscolus souzae McVaugh (Euphorbiaceae) are the most abundant. This vegetation type will henceforth be referred to as Hechtia-Agave association (HAA).

H. schottii is only known from the Mexican portion of the Yucatan Peninsula (Yucatan and Campeche; Ramírez and Carnevali 1999). It grows on HAA and SLCF. Population density of the species differs between habitat types, being less common in SLFC than in HAA association $\left(26 \mathrm{ind} / 10 \mathrm{~m}^{2}\right.$ in SLCF compared with $66.25 \mathrm{ind} / \mathrm{m}^{2}$ in HAA; Ramírez et al., unpubl. data); sex ratios also differ between both habitats being more balanced in HAA association compared to SLCF (2.31 staminate/pistillate individuals in HAA compared to 30:1 in SLCF, Ramírez et al., unpublished data). Causes of the differences of density and sex ratios among habitats are unknown but are probably related to light requirements and disturbances of habitat during henequen (Agave fourcroydes Lem.) cultivation. Herbarium specimens were deposited at Herbarium CICY (catalog numbers 4118-27, 4539, and 44821).

Phenology: phenological stages of the Hechtia populations were followed for eighteen consecutive months, from September 1997 through March 1999. In order to record phenology, five plots of 10x10 m were delimited, two of them in SLCF and three in HAA; individuals were permanently marked with metal or plastic tags and data such as flowering and/or fruiting per individual ramet were recorded monthly or bimonthly. During the peak of the flowering season (dry season), we conducted studies of floral, reproductive, and pollination biology on both sexes; sex of the individual ramets was determined based on presence of fruits, pistillate flowers and/or remnant carpels (as pistillates) and based on the presence of staminate flowers (as staminates). Results were then evaluated as staminate and pistillate flowering ramets as well as total flowering ramets and fruiting ramets in all five plots.

Floral biology: observations of floral biology were conducted during November 1997 (two days) and February 1998 (one day) in both floral morphs. Observations were conducted for three days, every $30 \mathrm{~min}$ for periods longer than $12 \mathrm{~h}$, from 4:30 to 18:00 h, recording anthesis (when the pollen is powder-like and sticks to the fingers; stigma is receptive when it looks sticky and pollen sticks to it), floral longevity (from opening to withering), pollen removal time, and fragrance emission. For fragrance emission, direct estimations were performed by smelling at flowers of both morphs.

Breeding system: these studies were carried out during November 1997 and February 1998. To determine the breeding system, after removal of old and open flowers, and fruits (in pistillate inflorescences), controlled crosses were performed as follows: (a) Automatic pollination (AP): buds were quantified and enclosed in pollination bags to assess whether or not the species self-pollinates and self-fertilizes (autogamy). (b) Natural pollination (NP): buds were quantified and left uncovered to evaluate natural fruit and seed set. (c) Self-pollination (SP): buds about to open next day were quantified and enclosed in a pollination bag; the following day the unopened buds were discarded and the open flowers were self-pollinated to evaluate self-compatibility. (d) Cross-pollination (CP): buds of both morphs about to open the next day were emasculated (pistillate flowers have staminodes) and enclosed in a pollination bag; next day pollen from each morph (anthers and staminodes) was used to pollinate flowers of 
the opposite sex; unopened flowers were discarded and pollinated flowers were enclosed in a pollination bag. (e) Agamospermy (AP): buds of both morphs were selected and emasculated; then enclosed in a pollination bag to test for apomixis. In all crosses, fruit production was evaluated two months later.

Floral visitors: insect visits (species and quantity) were recorded for each floral morph every $30 \mathrm{~min}$, from 4:30 to 18:00 h, during November 1997 (two days) and February 1998 (one day) in three plants by sex. We recorded number of insects and species, observing their behavior whenever possible with the aid of the naked eye. We captured insects on both floral morphs, using a lethal chamber with ethyl acetate, recording date, time, and flower sex. Pollen position on the insect body, insect species and pollen loads were studied and identified in the lab; pollen loads were compared with pollen samples collected from flowers from the same area during the flowering season of $H$. schottii to evaluate pollinator services. Plant species growing in the general area where the studies were conducted were collected and vouchers deposited at Herbarium CICY (catalog numbers 44111, 44112, 44114, 44116, $44460,44467,44480,44881)$; insects collected were identified with the assistance of the staff of the Enthomological Collection at the Universidad Autónoma de Yucatán (UADY), under the supervision of Dr. Hugo Delfín, curator of the collection.

\section{RESULTS}

Study organism: Hechtia schottii is a terrestrial, dioecious, rosetofilous herb with polycarpic monopodial ramets and a general sympodial growth habit. Ramets reach up to 1.5 $\mathrm{m}$ diameter and about $1 \mathrm{~m}$ tall except in SLCF where they reach up to $1.5 \mathrm{~m}$ tall. Basal or axilar long stolons are produced by ramets before and/or after reaching reproductive age; stolons produce apically a ramet (new rosette) that soon roots and becomes independent when it reaches maturity at approximately $1 / 3$ of the size of the mother rosette. Leaves are narrowly triangular, succulent, attenuate and long acuminate, green above, glaucous below, size and color may vary according with light conditions, leaf blades usually exceed $100 \mathrm{~cm}$ and about 5-6 cm wide at base, with serrate margins, the teeth being antrorse, 3-5 mm long, green or red tinged when exposed to strong sunlight.

Rosettes (ramets) produce 1-5 (-7) lateral inflorescences 1.5-2.5 m long. Staminate inflorescences are panicles, 1-2 (-3) pinnate, with numerous flowers per inflorescence $(2998.9 \pm 742.82, \mathrm{~N}=52)$. Pistillate inflorescences are also 1-2 (-3) pinnate panicles but with less flowers per inflorescence (1 $466.8 \pm 467.6$, $\mathrm{N}=16$ ) and with fewer branches with longer internodes. Scape, branches, floral bracts, sepals, and petals are covered with an epicuticular wax in both sexes. Flowers are sessile, unisexual, $0.8-1 \mathrm{~cm}$ long. Sepals in both sexes are brown, papiraceous, very reduced in size as compared to petals, brown and with a waxy cover; petals in both morphs are white. Pistillate flowers (Fig. 1A) have well-developed ovaries with three white stigmatic lobes, the six staminodes rest over broad filaments and consist of minute globose structures; staminate flowers have six stamens with dorsifixed green anthers and a rudimentary empty pistillode with three erect stigma remnants (Fig. 1B); floral bracts in both morphs are nerved and shorter than sepals. Fruits are deshicent, dry capsules with dry winged seeds. Seeds are aproximately 25 per fruit and weight individually ca. $0.008 \mathrm{~g}$.

Phenology: we quantified a total of 231 individuals in all five plots and recorded flowering and fruting on thirtheen censuses (every 1 or 2 months), where 179 individuals flowered at least once during the study period (136 with staminate flowers and 43 with pistillate flowers; 52 additional plants never bloomed) (Table 1). Results show (Fig. 2) simultaneous blooming peaks for both morphs with a conspicuosly larger amount of blooming staminate ramets compared with pistillate ramets during the study period except for plot HAA-2, where 

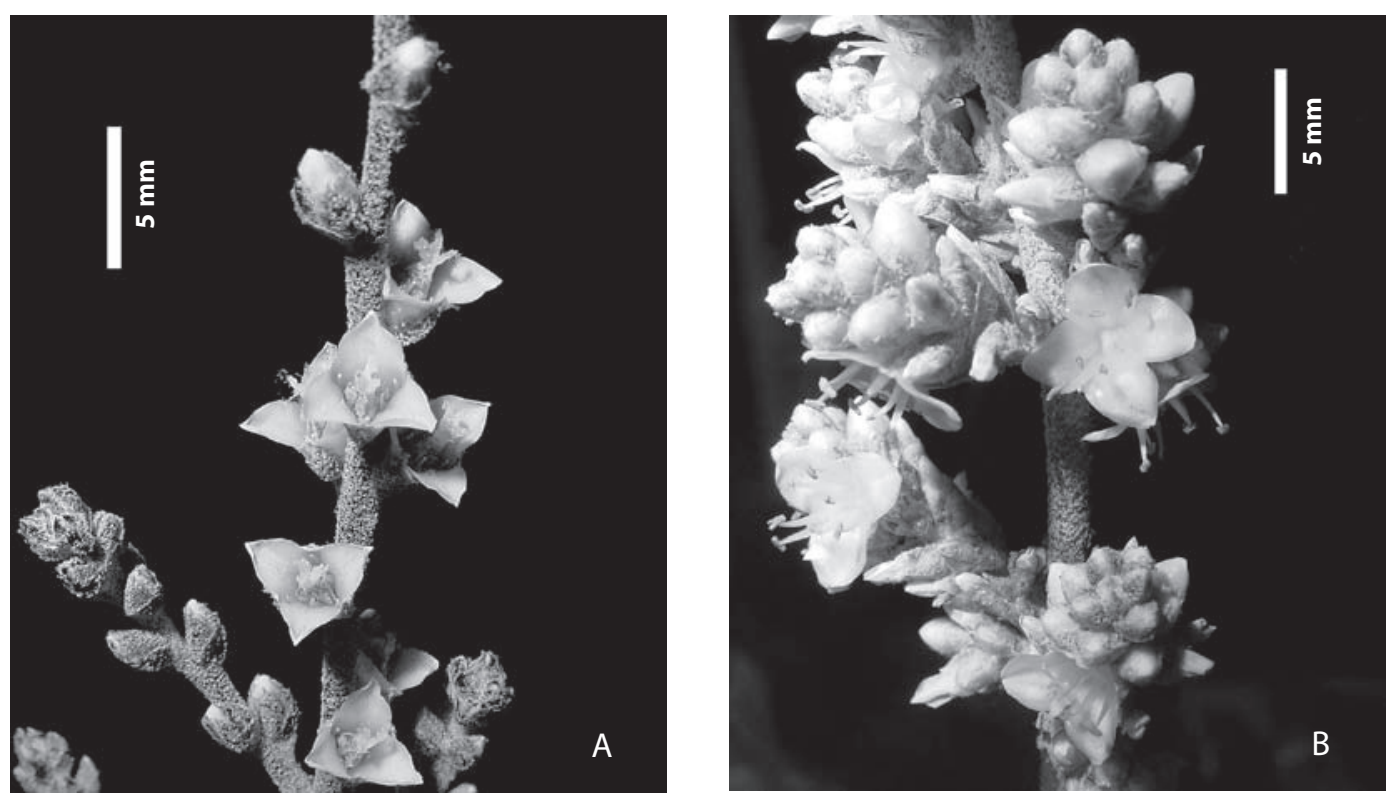

Fig. 1. A) Pistillate flowers, B) Staminate flowers.

pistillate plants in bloom were slightly superior in number to staminate plants (Table 1). During July-September 1998, no blooming was recorded in all plots probably due to the exceptionally dry summer of 1998 . The pattern of blooming for both morphs shows peaks during the same periods (December 1997-January 1998; February-March 1999) with a conspicuous decrement during March-November 1998.

Fruiting occurs right after pollination (Fig. 2), when the globose ovary begins to swell, forming a dry capsule with septicidal deshiscence; the dry, open carpels remain for 1-2 years on old, dry inflorescences. Fruit production followed by seed dispersal occurs at the end of the dry season and beginning of the rainy season (February-May 1998). Capsules deshice and seeds are exposed; these fall and drop on the inmediate entour; dispersal ratios appear to be very reduced unless moved by herbivores or rain to a favorable place to germinate and grow (usually rock crevices).

TABLE 1

Total number of ramets per plot (HAA: Hechtia-Agave association; SLCF: secondary low caducifolius forest), staminate and pistillate ramets as well as non-flowering ramets during 18 months observation period

$\begin{array}{ccccc}\text { Plot (type/number) } & \text { Staminate } & \text { Pistillate } & \text { Non-flowering } & \text { Total ramets } \\ \text { HAA-1 } & 20 & 6 & 3 & 29 \\ \text { HAA-2 } & 30 & 32 & 12 & 74 \\ \text { HAA-3 } & 55 & 4 & 17 & 76 \\ \text { SLCF-1 } & 13 & 1 & 2 & 16 \\ \text { SLCF-2 } & 18 & 0 & 18 & 36 \\ \text { TOTAL } & 136 & 43 & 52 & 231\end{array}$




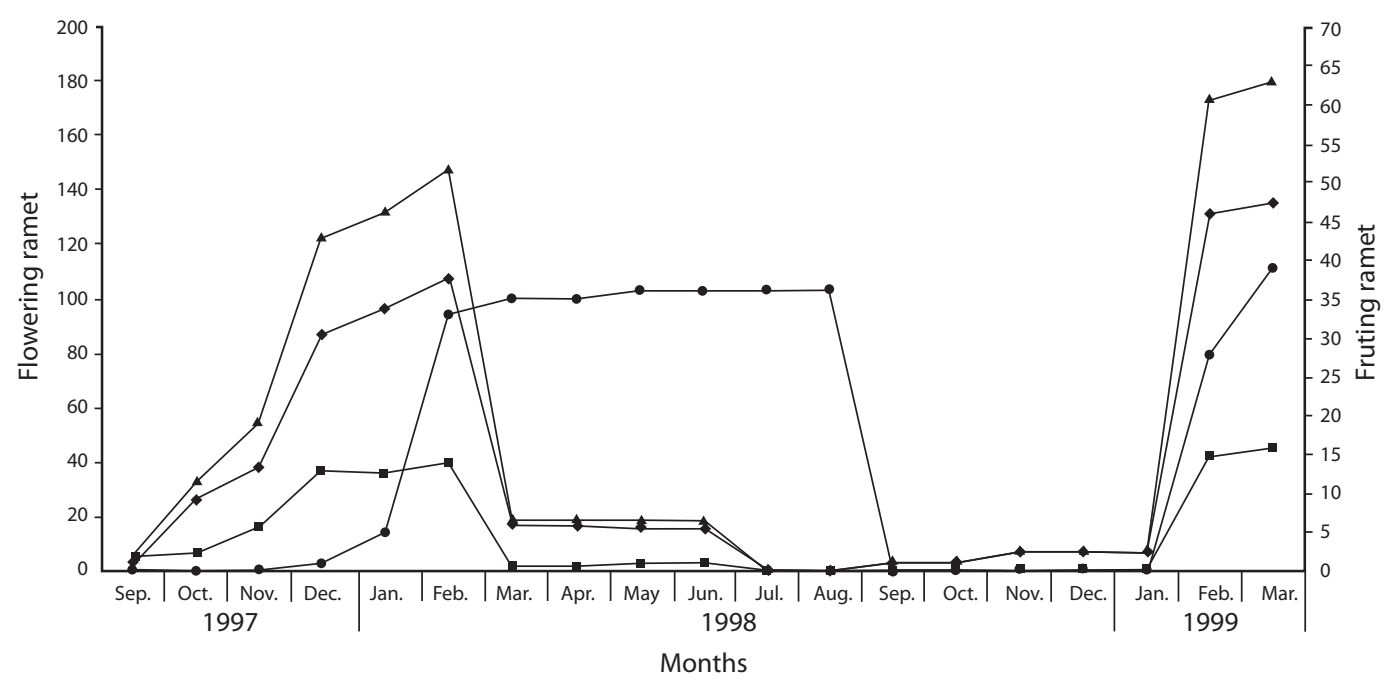

Fig. 2. Phenology of Hechtia schottii population in Calcehtok, based on data from five plots from September 1997 to March 1999. (rhombus: staminate flowering ramets; square: pistillate flowering ramets; triangle: flowering ramets; circles: fruiting ramets). Medium monthly temprature as well as preciptation is indicated for each month during the study period.

The seeds dispersed during 1998 were from fruits produced during the immediate previous flowering season. Seeds are naked, with a very small dry wing, narrowly elliptic, long acuminate at both ends, about $4 \mathrm{~mm}$ long, brown.

Floral biology: flowers of both sexes have diurnal anthesis, and they last only one day, remaining open for ca. $12 \mathrm{~h}$. Aproximately $2.04 \%$ of all staminate flowers to be produced by a single inflorescence open during any given day. Staminate flowers open early in the morning, around 5:00 $\mathrm{h}$ and remain open until 18:00 h, although they could open earlier (1:00-2:00 h) in exceptionally cool days. However, anthers deshice later, around 7:00-9:00 $\mathrm{h}$ and most pollen is removed by visitors (mostly bees), during the next few hours. Staminate flowers have white petals, six stamens, with versatile, green thecae displaying longitudinal deshicence, yellow pollen. They also feature a minute stigma and a relatively small pistiloid which is empty (no ovules observed) and much smaller than true ovaries in pistillate flowers. Nectar secretion was observed around the pistilloid, inside the petals.
On the other hand, around $2.3 \%$ of all pistillate flowers open daily in an inflorescence; pistillate flowers are sessile, with white petals, display a globose ovary, their stigma is short with three long, extended lobes, which are white, sticky, and glandular. They also feature six staminodes without anthers, which are connate to the base of the petals. Nectar secretion was observed around the ovary at base of petals. The amount of nectar is difficult to measure because of its small volumes. Ovule number varies little among locula based on ovula counted in 30 flowers $(9.24 \pm 2.05)$, as well as seeds per locula $(8.39 \pm 2.26)$ and seeds per fruit $(25.16 \pm 5.79)$, indicating also low percentage of ovule and seed abortion. Stigma enters anthesis (sticky and shiny surface) later in the morning, around 8:30 $\mathrm{h}$ and remains as such until 11:30 h despite of the fact that flowers remain open until 17-18 h.

Fruit set is high (ca. $100 \%$ ), as well as the average number of seeds per fruit (25.21 seeds/ fruit based on 40 fruits), and the number of fruits per meter of inflorescence (1300.19 fruits/m; 32777.9 seeds/inflorescence meter). 
Tests of fragrance emission by several parts of the flowers showed that only the petals emit perceptible fragrance in both morphs. Fragrance is emitted by both morphs but staminate flowers decrease the emission after pollen is removed. The aroma in staminate flowers is less perceptible, though sweeter and remaining longer, coming to an end about the time stigma receptivity fades, around 11:30 h. There is no detectable fragrance during the night.

Breeding system: results from controlled crosses (Table 2), show that $H$. schottii only produced fruits by natural pollination. Remnant filaments in pistillate flowers as well as pistiloids in staminate flowers are not functional based on the lack of fruit setting in cross and self pollinations within morphs. Fruit set for the natural pollination treatment is very high (ca. $100 \%$ ).

Floral visitors: insects initiate activity ca. one hour before anthesis: i.e., before anthers release pollen and stigma becomes sticky. In observations conducted for three days (5:30 until 17:00 h) and in three inflorescences of each sex, we recorded whether or not there was a sequence in the visitation pattern, and behavioral activity of each specific visitor species.

\section{TABLE 2}

Number of floral buds (pistillate and staminate) where different controlled crosses were performed; results measured as fruit set during february 1999

$\begin{array}{lcc}\text { Controlled Crosses } & \text { No. buds } & \text { No. fruits } \\ \text { Natural pollination (pistillate) } & 1396 & 1396 \\ \text { Natural pollination (staminate } & 976 & 0 \\ \text { Automatic pollination (pistillate) } & 203 & 0 \\ \text { Automatic pollination (staminate) } & 223 & 0 \\ \text { Selfing (pistillate) } & 6 & 0 \\ \text { Selfing (staminate) } & 8 & 0 \\ \text { Cross pollination (pistillate) } & 6 & 0 \\ \text { Cross pollination (staminate) } & 7 & 0 \\ \text { Agamospermy (pistillate) } & 8 & 0 \\ \text { Agamospermy (staminate) } & 6 & 0\end{array}$

Sixty two insects were captured in a period of $12 \mathrm{~h}$, of which $76 \%$ were collected on staminate flowers and $24 \%$ on pistillate flowers. Of these 62 insects, only 17 were carrying pollen loads; of these 15 were captured in staminate flowers and only two in pistillate flowers. Insects species identified include exotic and native bee species, which, besides pollen from $H$. schottii, were carrying pollen from several additional plant species (Table 3). Both floral morphs were visited by various bee species: Apis mellifera, Nannotrigona fulviventris, Partamona bilineata, and Trigona fulviventris. Activity was initiated by Apis mellifera followed by native meliponine species without an specific order. Ants were observed in pistillate flowers around the ovary where nectar is contained but their behavior excluded them from acting as legitimate pollinators as they visited flowers after anthesis.

Insects species carry pollen on the posterior legs while $A$. mellifera bees did it on the hairy abdomen as well. Results of pollen load analysis indicate that bee species with pollen loads in the study area are not specific for plant species, i.e., they collect pollen from several plants (Table 3). Plants in the community shared pollinators ("potential pollinators" since the assessment was based on pollen loads and not in actual observations of visiting behavior in these other plant species).

\section{DISCUSSION}

Flowering ramets show a staminate biased ratio typical of dioecious plantas (Vasiliauskas and Aarssen 1992, Forfang and Olesen 1998). Ramet population also shows a staminate biased ratio with staminates also producing more inflorescences and flowers, a common pattern observed in other dioecious plants (Cipollini and Whigham 1994, among others). A pattern of continuous blooming suggests that this species is a potentially important food resource for the insect community in the area, both for species using pollen or nectar, or both, especially during the dry season, 
TABLE 3

Insect species, number on individuals collected with pollen $(N)$ per insect species, and plant species which pollen was identified on insect bodies

Plant species / Insect species (N)

Hechtia schottii Baker (Bromeliaceae)

Passiflora ciliata Aiton (Passifloraceae)

Iresine diffusa Humb. and Bonpl. ex Willd.

(Amaranthaceae)

Viguiera dentata (Cav.) Spreng. var. helianthoides (Kunth) S. F. Blake (Asteraceae)

Croton peraeruginosus Croizat (Euphorbiaceae)

Cnidosculos aconitifolius (Mill.) I.M. Johnst. subsp. aconitifolius (Euphorbiaceae)

Capraria frutescens (Mill.) Britton (Scrophulariaceae)

Lantana camara L. (Verbenaceae)

Tecoma stans (L.) Juss ex Kunth (Bignoniaceae)

$\begin{array}{cccc}\text { Apis } & \text { Trigona } & \text { Partamona } & \text { Nannotrigona } \\ \text { mellifera } & \text { fulviventris } & \text { bilineata } & \text { perilampoides } \\ (8) & (4) & (2) & (3)\end{array}$

$+$

$+$

$+$

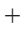

$+$

$+$

$+\quad+$

$+$

Numbers on parentesis indicate the number of individuals captured per insect species; + if presence of pollen on insect species.

making $H$. schottii potentially a key stone species in this particular community. Fruting and dispersing seeds just at the beginning of the rainy season would allow seeds to germinate and seedlings to become stablished before the onset of the following dry season.

On the other hand, the phenological pattern is also characteristic of many plants from dry areas, i.e., blooming during the dry season. These results agree with those found in other phenological studies in dry areas (Janzen 1967, Opler et al. 1980). However, phenological patterns change from year to year, probably in relation to global fluctuations of factors such as temperature and precipitation (length of the rainy season and distribution change from year to year).

The general flowering pattern of populations of $H$. schottii in the study site is similar to most of those displayed on other studies involving dioecious species (Forfang and Olesen 1998, Armstrong and Irvine 1989, Freeman et al. 1976) where a staminate-biased floral sex ratio was found. However, floral sex ratio could be pistillate-biased in areas where plant sex ratio is pistillate biased (Lovett et al.1987). Spatial segregation of sexes has been reported for grasses where pistillate plants were more abundant in areas with higher moisture availability (Freeman et al.1976, Fox and Harrison 1981); staminates were proportionately more abundant on xeric sites than on mesic sites compared to pistillates (Freeman et al. 1976). Niche differentiation between sexes is explained by the disparity in reproductive investment of the sexes and higher resource demand by pistillates for seed production (Bawa and Opler 1975, Dawson and Ehleringer 1993).

In H. schottii, pistillate inflorescences have more flowers than staminate inflorescences. Also, there are less pistillate than staminates flowers opening daily, a situation found in many dioecious plants as a way to guarantee cross pollination. After insect visitation of staminate flowers, anthers become deflexed and 
turn a green hue, possibly a clue to potential visitors that rewards are low and that it might be better to visit another flower in the same (or other) inflorescence. Pistillate flowers do not show the same grade of morphological changes as staminate flowers; however, the stigma changes its glossy appereance as anthesis fades. Both flower types last one day and each individual inflorescence keeps producing flowers for a period of aproximately 30 days.

Considering the amount of open flowers daily, the pollen produced per anther, as well as the pollen load per insect, we suggest that the species could represent an important pollen and nectar resource to the melithophilous community (even a keystone species) in the area since there are blooming individuals along the whole year and visited by several species.

Populations of $H$. schottii in the study area are morphologically and functionally dioecious and require cross-pollination for sexual reproduction. The pistillode of staminate flowers did not have ovules and thus did not set seeds, as well as pistillate flowers did not have pollen in the staminodes. On the other hand, we did not observe plants bearing simultaneously staminate and pistillate flowers as well as there is no evidence of sex changing from one to the next flowering season, i.e., no evidence of morphologically staminate and pistillate flowers on the same individual. Further confirmation of this fact springs from the fact that cultivated plants of the species at the Jardín Botánico Regional of CICY have been under observance for several years without any evidence of sex shifts. Thus, possibility of $H$. schottii being monoecious or hermaphrodite can be ruled out.

Frut setting is high $(100 \%$ of pistillate flowers pollinated) and suggests that pollination activity is very effective. This suggests that either or both seed germination and seedling survival at the early stages act as effective bottlenecks to the increase in size of this particular population. This suggestion is supported by the fact that seedlings were rarely found in the study site. The severity of the dry season, the frequent fires, the shallowness of the soils, and human disturbances probably act as severe selective pressures for the genotypes that eventually become established in the general Calcethok area. The same is probably true for most known populations of $H$. schottii which usually occur in dry rocky or otherwise unfavourable and marginal environments. On the other hand, the increase in biomass of the Calcethok population of $H$. schottii is mostly due to the stoloniferous growth of the genets, as described above. This phenomenon guarantees the survival of the relatively few genotypes present in the population, and thus the permanence of the population even through long periods of low or null seedling recruitment.

Visitor insects form an assemblage of bees that feed on pollen and nectar and H. schottii provides both rewards to them. Based on pollen loads of $H$. schottii identified on insect bodies, all four bee species could be potential pollinators of the species. However, of all bees collected on pistillate inflorescences, only A. mellifera was detected carrying pollen of $H$. schottii. It is apparent from the experiments and evidence presented here (no other bee species that visited pistillate flowers carried Hechtia pollen loads) that $A$. mellifera has currently displaced the original pollinators at the study site (and probably in most of the current distributional range of $H$. schottii since A. mellifera is widespread in the Yucatan Peninsula). Since A. mellifera is an exotic bee species, it is difficult to stablish with certainty which of the other bees, if any, that visited $H$. schottii at the study site was the former pollinator(s) before the introduction of A. mellifera.

This study is the first quantitative study of the reproductive biology of any dioecious bromeliad. The study is also relevant since it deals with the reproductive biology of a possible keystone species, a taxon that constitutes an important source of pollen and nectar to the bee population at the study site throughout the year.

Twenty to thirty years before this study was conducted, the study area was an Agave fourcroydes (henequén) plantation. Once the cultivation of this species dwindled down due to the introduction of synthetic fibers in the international market (about the early 1960's), 
the lands were abandoned and various types of natural vegetation (along with an abundance of exotic species) started to re-colonize these fields. H. schotti, a species naturally suited to grow on shallow, rocky places, became a natural member of this pioneer community. It is apparent that populations of $H$. schotti were able to colonize the abandoned lands. Simultaneously, the climax vegatation of the area, the SLCF started to come back, eventually changing dramatically enviromental conditions under which the first Hechtia colonizers grew. These original Hechtia plants eventually became large plants with elongated (ethyolated) leaves, featuring low flowering rates due to the shady conditions prevalent in these places. All this, associated with the fact that the area is burned periodically, eventually caused serious damages to the reproduction of this species by affecting seedling and adult plants.

\section{ACKNOWLEDGMENTS}

To Comisión Nacional para el conocimiento y uso de la biodiversidad (CONABIO) for finantial support for field work (Project MO63); to Nelson Ramírez for advise on field work. Guadalupe Chuc Puc helped with the identification of pollen on insect bodies; Lilia Can for searching and providing vouchers information from Herbarium CICY data base.

\section{RESUMEN}

Hechtia schottii es una hierba terrestre, suculenta, rosetófila, dioica y policárpica, que crece en asociaciones arbustivas y selva baja caducifolia secundaria, ambos en suelos calcáreos o limosos. Estudiamos la fenología, la biología floral, reproductiva y de la polinización en una población en Calcehtok, Yucatán, México, durante dos estaciones de floración. Las plantas florecen principalmente en la época de secas (noviembre-abril) y la dispersión de semillas es durante la estación de lluvias (mayo-octubre). Ambas formas (morphs) florales tienen antesis diurna; el polen es removido ca. $1 \mathrm{~h}$ después del comienzo de la antesis y ambas formas florales son visitadas por varias especies de insectos, especialmente abejas, pero los resultados sugieren que la abeja introducida, Apis mellifera, es el polinizador. Cruces controlados muestran que la especie es funcionalmente dioica y que requiere de un polinizador, ya que solo produce frutos por polinización no asistida entre formas.

Palabras clave: Hechtia schottii, Bromeliaceae, biología reproductiva, dioico, polinizador, Mexico, Yucatán.

\section{REFERENCES}

Armstrong, J.E. \& A.K. Irvine. 1989. Flowering, sex ratios, pollen-ovule ratios, fruit set, and reproductive effort of a dioecious tree, Myristica insipida (Myristicaceae), in two different rain forest communities. Amer. J. Bot. 76: 74-85.

Bawa, K.S. 1980. Evolution of dioecy in flowering plants. Ann. Rev. Ecol. Syst. 11: 15-39.

Bawa, K.S. \& P.A. Opler. 1975. Dioecism in tropical trees. Evolution 29: 167-179.

Benzing, D., H. Luther \& B. Bennett. 2000. Reproduction and life history, p. 245-328. In D. Benzing (ed.). Bromeliaceae, profile of an adaptive radiation. Cambridge University, Cambridge, U.K.

Burt-Utley, K. \& J.F. Utley. 1993. Two new species of Hechtia (Bromeliaceae, Pitcairnioideae) from western Mexico. Brittonia 45: 219-225.

Cipollini, M.L. \& D.F. Whigham. 1994. Sexual dimorphism and cost of reproduction in the dioecious shrub Lindera benzoin (Lauraceae). Am. J. Bot. 81: 65-75.

Dawson, T.E. \& J.R. Ehleringer. 1993. Gender-specific physiology, carbon isotype discrimination, and habitat distribution in boxelder, Acer negundo. Ecology 74: 789-815.

Duch, G.J. 1988. La conformación territorial del estado de Yucatán: Los componentes del medio físico. FAO/ UNESCO, Universidad Autónoma de Chapingo, México.

Ferrusquía-Villafranca, I. 1993. Geology of Mexico: A synopsis, p 3-108. In T.P. Ramamoorthy, R. Bye, A. Lot \& J. Fa (eds.). Biological Diversity of Mexico: Origins and Distribution. Oxford University, New York, USA.

Forfang, A.S. \& J.M. Olesen. 1998. Male-biased sex ratio and promiscuous pollination in the dioecious island tree Laurus azorica (Lauraceae). Plant Syst. Evol. 212: $143-157$. 
Fox, J.F. \& T. Harrison. 1981. Habitat assortment of sexes and water balance in a dioecious grass. Oecologia 49: 233-235.

Freeman, D.C., L.G. Klikoff \& K.T. Harper. 1976. Differential resource utilization by the sexes of dioecious plants. Science 193: 597-599.

Humeau, L., T. Pailler \& J.D. Thompson. 1999. Cryptic dioecy and leaky dioecy in endemic species of Dombeya (Sterculiaceae) on La Reunion. Am. J. Bot. 86: $1437-1447$.

Janzen, D.H. 1967. Synchronization of sexual reproduction of trees within the dry season in Central America. Evolution 21: 620-637.

Lenz, L.W. 1995. A new species of Hechtia (Bromeliaceae, Pitcairnioideae) from the Cape Region, Baja California Sur, Mexico. Aliso 14: 59-61.

Lovett Doust, J., G. O’Brien \& L. Lovett Doust. 1987. Effect of density on secondary sex characteristics and sex ratio in Silene alba (Caryophyllaceae). Am. J. Bot. 74: 40-46.

Olmsted, I., R. Durán, J.A. González-Iturbe, J. Granados \& F. Tun. 1999. Vegetación, p. 183-194. In A. García \& J. Córdoba (eds.). Atlas de Procesos Terriotoriales de Yucatán. Universidad Autónoma de Yucatán, Fac. Arquitectura, Mérida, Yucatán, México.

Opler, P.A., G.W. Frankie \& H.G. Baker. 1980. Comparative phenological studies of treelet and shrub species in tropical wet and dry forests in the lowlands of Costa Rica. J. Ecol. 68: 167-188.

Palací, C.A. 1997. A systematic revision of the genus Catopsis (Bromeliaceae). Thesis for the degree of Doctor of Philosophy in Botany. University of Wyoming, Laramie, Wyoming.

Ramírez, M., I.M. \& G. Carnevali F.C. 1999. A new species of Tillandsia, some new records, and a checklist of the Bromeliaceae from the Yucatan Peninsula. Harv. Pap. Bot. 4: 185-194.

Renner, S.S. \& R.E. Ricklefs. 1995. Dioecy and its correlates in the flowering plants. Am. J. Bot. 82: 596-606.

Smith, L.B. \& R.J. Downs. 1974. Pitcairnioideae (Bromeliaceae). Flora Neotropica. Monograph 14: 1-658.

Smith, L.B. \& R.J. Downs. 1977. Tillandsioideae (Bromeliaceae). Flora Neotropica. Monograph 14: $663-1492$

Smith, L.B. \& R.J. Downs. 1979. Bromelioideae (Bromeliaceae). Flora Neotropica. Monograph 14: 1493-2142.

Vasiliauskas, S.A. \& L.W. Aarssen. 1992. Sex ratio and neighbor effects in monospecific stands of Juniperus virginiana. Ecol. Soc. Am. 73: 622-632.

Weiblen, G.D., R.K. Oyama \& M.J. Donogue. 2000. Phylogenetic analysis of dioecy in Monocotyledons. Am. Nat. 155: 46-58. 
